\title{
PENGARUH IKLIM ORGANISASI DAN BUDAYA ORGANISASI TERHADAP KINERJA GURU DI SMA NEGERI 1 PARIANGAN
}

\author{
${ }^{1}$ Renil Fortunately, ${ }^{2}$ Asmendri, ${ }^{3}$ M. Haviz \\ ${ }^{1}$ Mahasiswa Program Pascasarjana IAIN Batusangkar., ${ }^{1,2}$ IAIN Batusangkar \\ email: ${ }^{1}$ fortunatelyrenil27@gmail.com, ${ }^{2}$ asmendri@iainbatusangkar.ac.id,
}

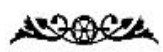

\begin{abstract}
This study aimed to assess the effect of organizational climate on teacher performance, organizational culture on teacher performance and assess the effect of organizational climate and organizational culture together on the teacher performance in SMA Negeri 1 Pariangan. The sample of the study involved 48 teachers in SMA Negeri 1 Pariangan by using total sampling technique. The data were collected by using questionnaire. The findings revealed that (1) Organizational climate significantly influence the performance of teachers in SMA Negeri 1 Pariangan. (2) Organizational culture significant effect on the performance of teachers in SMA Negeri 1 Pariangan. (3) Organizational climates and organizational culture together significant effect on the performance of teachers in SMA Negeri 1 Pariangan.
\end{abstract}

Keywords: Organizational Climate, Organizational Culture, Teacher Performance

\section{PENDAHULAN}

Pendidikan mempunyai peranan yang sangat penting dalam kemajuan suatu bangsa dan negara, karena melalui pendidikan kita bisa meningkatkan dan mengembangkan kualitas sumber daya manusia. Dalam hal ini guru merupakan salah satu faktor penentu dalam keberhasilan suatu pendidikan. Mulyasa (2005: 9) mengatakan bahwa keberhasilan pembaruan sekolah sangat ditentukan oleh gurunya, karena guru adalah pemimpin pembelajaran, fasilitator dan sekaligus merupakan pusat inisiatif pembelajaran.

Begitu besar peran guru dalam keberhasilan suatu pendidikan, sehingga guru disebut sebagai ujung tombak dalam upaya peningkatan kualitas pendidikan. Sebagaimana pendapat Saifulloh dan Hermanto (2012: 208) yang mengatakan bahwa kepala sekolah dan guru mempunyai tanggung jawab besar terhadap peningkatan mutu pendidikan di sekolah. Tetapi pada kenyataannya kinerja guru di Indonesia masih rendah. Menteri keuangan Sri Mulyani mengatakan bahwa ada sekitar 4 juta guru yang setiap tahunnya dibayar pemerintah tetapi kinerjanya tidak kompeten (Okezone, Kamis 23 November 2017 20: 21 WIB). Oleh karena itu, kinerja guru menjadi poin penting dalam meningkatkan kualitas pendidikan di Indonesia.

Kinerja guru dapat dilihat dari sejauh mana kinerja tersebut dapat memberikan pengaruh kepada anak didik (Hutasoit, 2016: 2). Sementara itu Pratiwi (2013: 90) menyatakan bahwa kualitas kinerja guru sangat berpengaruh terhadap terwujudnya keberhasilan pendidikan di sekolah. Seorang guru yang mempunyai kinerja tinggi diharapkan lebih produktif dan keberhasilan kerjanya tinggi. Tetapi kinerja atau prestasi kerja tidak bisa muncul begitu saja, namun dipengaruhi oleh beberapa faktor di antaranya iklim organisasi dan budaya organisasi.

Menurut Glisson (2007) dalam Rusu dan Avasilcai (2013: 52) organizational climate 
is defined as the employees subjective perceptions of how their work environtment affects them as individuals. Menurut Firmansyah dan Santy (2011: 225-253), iklim organisasi pada dasarnya akan mampu memunculkan suasana kerja yang menyenangkan, iklim organisasi yang kondusif akan mendorong karyawan untuk bekerja dengan baik. Iklim organisasi sebagai suatu sistem sosial yang dipengaruhi oleh lingkungan eksternal dan internal yang salah satunya adalah budaya organisasi.

Kurniadin dan Machali (2012: 246) mengemukakan bahwa budaya organisasi merupakan pola sikap, keyakinan, asumsi, dan harapan yang dimiliki bersama, yang mungkin tidak dicatat, tetapi membentuk cara bagaimana orang-orang bertindak dan berinteraksi dalam organisasi dan mendukung bagaimana hal-hal dilakukan. Budaya organisasi berdampak pada kinerja jangka panjang organisasi, bahkan mungkin merupakan faktor penting dalam menentukan keberhasilan atau kegagalan organisasi. Meskipun tidak mudah berubah, budaya organisasi dapat meningkatkan kinerja (Wibowo, 2001: 487).

Berdasarkan observasi dan wawancara peneliti pada 25 Juli 2018 berkenaan dengan Kinerja Guru di SMAN 1 Pariangan masih berada pada kondisi yang wajar (wawancara dengan Kepala SMA Negeri 1 Pariangan Bapak Drs. Edison, M.M). Fenomena yang terlihat belum optimalnya kinerja guru baik itu perencanaan, pelaksanaan maupun evaluasi pembelajaran. Permasalahan yang sering terjadi diantaranya: waktu tidak mencukupi dalam menyampaikan materi pembelajaran, beberapa guru terkesan belum menjalankan fungsinya sebagai pendidik, belum profesional dalam menyusun RPP, media dan metode pembelajaran belum bervariasi. Berdasarkan uraian tersebut, maka peneliti merasa penelitian tentang. "Pengaruh Iklim Organisasi dan Budaya Organisasi Terhadap Kinerja Guru di SMA Negeri 1 Pariangan” penting untuk dilakukan.

\section{IKLMORGANSASI}

Menurut Sarjana (2012: 173-186) iklim organisasi merupakan suasana organisasi yang mendukung pelaksanaan pekerjaan. Iklim organisasi merupakan serangkaian deskripsi dari karakteristik organisasi yang membedakan organisasi dengan organisasi lainnya yang mengarah pada persepsi masing-masing anggota dalam memandang organisasi. Rahimic (2013: 129-139) menyebutkan iklim organisasi sebagai persepsi karyawan terkait aspek pekerjaan dan nilai-nilai organisasinya. Dari beberapa pendapat tersebut dapat disimpulkan bahwa iklim organisasi adalah persepsi masingmasing pegawai mengenai karakteristik dan kondisi organisasi yang memengaruhi perilaku pegawai dalam menjalankan pekerjaannya.

Adapun indikator iklim organisasi menurut Hardjana (2006: 26) antara lain: (1) tanggung jawab kerja yaitu tugas dan peran yang didelegasikan oleh pimpinan, berani menanggung resiko, kesediaan menghadapi berbagai karakteristik peserta didik, serta penggunaan waktu dan tenaga dengan baik; (2) hubungan antarpersonil berupa keramahan, keterbukaan, musyawarah mufakat, serta tenggang rasa antar guru; dan (3) dukungan kerja yaitu suasana nyaman dan damai, serta saling bahu-membahu dalam kegiatan sekolah. 


\section{BUDAYAORGANSASI}

Kurniadin dan Machali (2012: 246) menyatakan bahwa budaya organisasi merupakan pola keyakinan dan nilai-nilai organisasi yang dipahami, dijiwai, dan dipraktekkan organisasi sehingga pola tersebut memberikan arti tersendiri dan menjadi dasar aturan berperilaku dalam organisasi. Menurut Mulyadi (2010: 90) budaya organisasi adalah seperangkat asumsi dasar yang diciptakan, ditemukan, atau dikembangkan dan dianut bersama sebagai pembelajaran untuk mengatasi masalah-masalah adaptasi dengan lingkungan eksternal dan integrasi internal. Dari pendapat di atas dapat ditarik kesimpulan bahwa yang dimaksud dengan budaya organisasi adalah seperangkat asumsi atau keyakinan, nilai-nilai dan norma yang dikembangkan dalam organisasi yang dijadikan pedoman tingkah laku bagi anggota-anggotanya untuk mengatasi masalah adaptasi eksternal dan integrasi internal.

Soetopo (2010: 130-131) mengemukakan bahwa karakteristrik suatu budaya organisasi adalah sebagai berikut: (1) inisiatif individual, yaitu tingkat tanggung jawab, kebebasan atau indepedensi yang dipunyai setiap anggota organisasi; (2) toleransi terhadap tindakan berisiko, yaitu suatu budaya organisasi yang dapat memberikan toleransi kepada anggota untuk bertindak agresif dan inovatif; (3) pengarahan yaitu sejauh mana organisasi dapat menciptakan dengan jelas sasaran dan harapan yang diinginkan; (4) integrasi yaitu sejauh mana organisasi dapat mendorong bekerja dengan cara yang terkoordinasi; (5) dukungan manajemen maksudnya dapat memberikan komunikasi atau arahan, bantuan serta dukungan yang jelas terhadap bahawan; (6) kontrol dengan alat kontrol berupa peraturan-peraturan atau norma-norma yang berlaku dalam suatu organisasi; (7) identitas yang dimaksud sejauh mana para anggota suatu organisasi dapat mengidentifikasikan dirinya sebagai satu kesatuan dalam organisasi; (8) sistem imbalan didasarkan atas prestasi kerja pegawai; (9) toleransi terhadap konflik; (10) pola komunikasi yaitu sejauh mana komunikasi dibatasi oleh hierarki kewenangan yang formal.

\section{KINERI AGURU}

Menurut Hanafi (2006: 6) kinerja adalah penampilan hasil karya personel baik kuantitas maupun kualitas dalam suatu organisasi dan merupakan penampilan individu maupun kelompok kerja personil. Mulyasa (2005: 136) mendefenisikan kinerja sebagai prestasi kerja, pelaksanaan kerja, pencapaian kerja, hasil kerja atau unjuk kerja. Dari pendapat diatas dapat disimpulkan bahwa kinerja adalah prestasi kerja atau pencapaian kerja seseorang dalam melaksanankan tugas-tugas yang dibebankan kepadanya yang dapat dinilai dari hasil karyanya baik secara kuantitas maupun kualitas.

Secara terperinci Umar (2007: 79) mengungkapkan beberapa indikator yang dapat dilihat berkenaan dengan peran guru dalam meningkatkan kemampuan dalam proses belajar mengajar. Indikator kinerja tersebut adalah sebagai berikut: (1) kemampuan merencanakan belajar mengajar, meliputi: menguasai garis-garis besar penyelenggaraan pendidikan, menyesuaikan analisis materi pelajaran, menyusun program semester, menyusun program atau pembelajaran; (2) kemampuan melaksanakan kegiatan belajar mengajar, meliputi: 
tahap pra intruksional, tahap intruksional, tahap evaluasi dan tidak lanjut, dan (3) kemampuan mengevaluasi, meliputi: evaluasi normatif, evaluasi formatif, laporan hasil evaluasi, pelaksanaan program perbaikan dan pengayaan.

\section{METODOLOG}

Penelitian ini menggunakan pendekatan kuantitatif yang menggunakan jenis penelitian studi korelasional kausalitas. Penelitian dilakukan di SMA Negeri 1 Pariangan mulai dari bulan Mei - Desember 2018. Variabel penelitian terdiri dari independent variabel (bebas) yaitu iklim organisasi dan budaya organisasi sedangkan dependent variable (terikat) kinerja guru. Populasi penelitian sebanyak 48 Guru di SMA Negeri 1 Pariangan. Sampel pada penelitian ini adalah sampling jenuh atau disebut juga dengan total sampling. Jenis dan sumber data dalam penelitian ini adalah data primer dengan menggunakan kuesioner. Teknik pengumpulan data yang digunakan dalam penelitian ini adalah metode wawancara dan instrumen yang digunakan adalah angket.

Uji validitas instrumen dilakukan dengan pengukuran validitas butir menggunakan teknik korelasi product moment. Uji reliabilitas instrument menggunakan teknik Alfa Cronbach. Teknik analisis data yang digunakan meliputi: (1) pendeskripsian data; (2) pengujian persyaratan analisis terdiri dari uji normalitas data, uji linearitas, uji multikolinearitas; (3) pengujian hipotesis yang terdiri dari uji regresi sederhana dan uji regresi ganda.

\section{HASIL PENEUTIAN}

\section{Iklim Organisasi (X1)}

Skor iklim organisasi yang berada di kelas interval rata-rata adalah $39,60 \%$ diatas kelas interval $10,41 \%$ dan dibawah skor 18,75\%. Tingkat pencapaian skor iklim organisasi adalah hasil bagi rata-rata dengan skor maksimal ideal dan dikali 100\%. Ulasannya yaitu 59,31: $70 \times 100 \%=84,73 \%$ (termasuk kategori baik). Hasil ini menunjukkan bahwa iklim organisasi tersebut baik. Selanjutnya tingkat pencapaian skor iklim organisasi temasuk baik (86,1\%). Hasil ini menunjukkan bahwa iklim organisasi di SMA Negeri 1 Pariangan termasuk kategori baik.

Secara rinci dapat dijelaskan bahwa indikator pertama iklim organisasi yaitu tanggung jawab kerja, dengan tingkat pencapaian $86,1 \%$ atau kategori baik. Indikator kedua hubungan antar personil disekolah, dengan tingkat pencapaian $83,72 \%$ atau kategori baik, dan indikator ketiga dukungan kerja dengan pencapaian $84,56 \%$ dengan kategori juga baik.

\section{Budaya Organisasi}

Skor budaya organisasi yang berada di kelas interval rata-rata adalah $20,83 \%$ diatas kelas interval rata-rata $18,75 \%$ dan dibawah skor $16,67 \%$. Tingkat pencapaian skor budaya organisasi adalah hasil bagi rata-rata dengan skor maksimal ideal, yaitu 120,04 : $135 \times 100 \%=88,91 \%$ (termasuk kategori baik). Hasil ini menunjukkan bahwa budaya organisasi di SMA Negeri 1 Pariangan termasuk kategori baik. Selanjutkan tingkat pencapaian skor budaya organisasi 91,33\% termasuk kategori sangat baik. Hasil ini menunjukkan bahwa budaya organisasi di 
SMA Negeri 1 Pariangan termasuk kategori sangat baik.

Secara rinci dapat dijelaskan bahwa indikator pertama budaya organisasi yaitu inisiatif individual, dengan tingkat pencapaian 90,53\% berada pada kategori sangat baik. Selanjutnya indikator toleransi dengan tingkat pencapaian $87,2 \%$ atau baik. Indikator pengarahan dengan pencapaian 86,8\% atau baik. Indikator integrasi dengan pencapaian $84,4 \%$. Indikator dukungan manajemen dengan pencapaian $87,2 \%$ atau baik. Indikator kontrol dengan pencapaian 91,33\% berada pada kategori sangat baik. Indikator identitas dengan pencapaian $89,5 \%$ atau baik. Indikator sistem imbalan dengan pencapaian 90,13 atau sangat baik. Indikator toleransi terhadap konflik dengan pencapaian 91,2\% kategori sangat baik. Indikator pola komunikasi dengan pencapaian 90,8\%atau kategori sangat baik.

\section{Kinerja Guru}

Skor kinerja yang berada di kelas interval rata-rata adalah 33,33\% diatas kelas interval rata-rata $4,17 \%$ dan dibawah skor $20,83 \%$. Tingkat pencapaian skor kinerja guru adalah hasil bagi rata-rata dengan skor maksimal ideal, yaitu 64,87: $75 \times 100 \%=$ 86,49\% (termasuk kategori baik). Hasil ini menunjukkan bahwa kinerja guru termasuk kategori baik. Selanjutnya tingkat pencapaian skor kinerja guru termasuk baik $(87,2 \%)$. Hasil ini menunjukkan bahwa budaya organisasi di SMA Negeri 1 Pariangan termasuk kategori baik.

Secara rinci dapat dijelaskan bahwa indikator pertama kinerja guru yaitu perencanaan pembelajaran, dengan tingkat pencapaian $86,64 \%$ atau kategori baik. Selanjutnya indikator kedua pelaksanaan pembelajaran dengan tingkat pencapaian
$87,2 \%$ dengan kategori baik dan Indikator evaluasi pembelajaran dengan tingkat pencapaian $85 \%$ juga kategori baik.

\section{Y I PERSYARATANANAUSIS}

\section{Hasil Uji Normalitas}

Dalam penelitian ini uji normalitas menggunakan uji Kolmogorov-smirnov, kriterianya adalah signifikansi untuk uji satu sisi hasil perhitungan lebih besar dari $>0,05$ berarti berdistribusi normal. Dari hasil uji normalitas dapat dinyatakan bahwa angka signifikan (asymp.sig) sebesar 0,200 lebih dari nilai $\alpha$ dengan (sig) $>0,05$. Dapat disimpulkan bahwa Ho diterima dengan kata lain ketiga variabel tersebut dapat dikatakan berdistribusi normal.

\section{Hasil Uji Linearitas}

Hasil uji linearitas menunjukkan bahwa untuk semua kontribusi variabel bebas terhadap variabel terikat berada pada taraf signifikansi $>0,05$. sehingga dapat disimpulkan bahwa: (1) pengaruh antara iklim organisasi (X1) terhadap kinerja guru di SMA Negeri 1 Pariangan (Y) linier dan berarti; (2) Pengaruh antara budaya organisasi (X2) terhadap kinerja guru di SMA Negeri 1 Pariangan (Y) linier dan berarti.

\section{Hasil Uji Multikolinearitas}

Multikolinearitas dihitung untuk mengetahui bahwa variabel-variabel penelitian saling bebas, artinya tidak tergantung dengan variabel lainnya. Multikolinearitas dapat diketahui dari nilai VIF (Variance Inflation Factor) masing-masing variabel. Jika nilai VIF tidak melebihi 10 maka tidak terjadi multikolinearitas. Hasil pengujian masing-masing variabel menunjukkan bahwa besarnya nilai VIF untuk masing- 
masing variabel bebas $<10$. Dengan demikian masing-masing variabel bebas tersebut tidak mengalami multikoliniearitas.

\section{Y IHPOTESIS}

\section{Uji Hipotesis Pertama}

Hasil perhitungan pengaruh iklim organisasi terhadap kinerja guru, diperoleh harga korelasi $r y \times 1=0,448$ dengan determinasi $\mathrm{r}^{2} y \times 2=0,201$. Dengan demikian, 20,1\% variasi variabel kinerja dipengaruhi oleh variabel iklim organisasi. Koefisien regresi linier ganda diperoleh koefisien b1 sebesar 0,297 dengan signifikansi 0,019 , berarti terdapat pengaruh yang signifikansi antara variabel iklim organisasi terhadap kinerja guru di SMA Negeri 1 Pariangan. Dari hasil analisa diperoleh angka koefisien variabel iklim organisasi (ry1) sebesar 448 yang menunjukan bahwa pengaruh iklim organisasi terhadap kinerja guru berpengaruh signifikansi. Harga F sebesar 11.576 dengan nilai signifikan 0,001 yang lebih kecil dari alpha 0,05 atau taraf kepercayaan 95\% mengindikasikan bahwa persamaan regresi yang terbentuk antara variabel iklim organisasi terhadap kinerja guru dapat diterima dengan keberadaannya. Hasil dari pemeriksaan uji $\mathrm{T}$ diketahui bahwa nilai signifikasi sebesar 0,001, dengan konstanta 40. 733, sedangkan persamaan regresi sebesar 3.402, dan nilai signifikasi sebesar 0,001 lebih kecil dari nilai signifikasi alpha 0,05 . Dengan demikian dapat dijadikan alat prediksi untuk menentukan setiap gejala yang terjadi pada variabel iklim organisasi.

Dari penjelasan di atas diperoleh persamaan regresi sederhana yang digunakan yaitu $\mathrm{X} 2=\mathrm{a}+\mathrm{bX} 1$ yang didalamnya ada a dan $b$, masing-masing bernilai sebesar 40.733 dan 0.407. Dengan demikian persamaan regresinya adalah X2 = $40.733=0.407 \mathrm{X} 1$. Artinya bila iklim organisasi dikembangkan satu skala maka kinerja guru akan bertambah 0.407 skala. Jadi, dapat dikemukakan bahwa iklim organisasi berpengaruh signifikansi sebesar $20,1 \%$ terhadap variabel kinerja guru dan sisanya $79, \%$ ditentukan oleh faktor lain yang belum teramati.

\section{Uji Hipotesis Kedua}

Hasil perhitungan pengaruh iklim organisasi terhadap kinerja guru, diperoleh angka koefesien variabel budaya organisasi dengan kinerja guru (ry2) sebesar 0,446. Hasil uji $\mathrm{F}$ memperlihatkan harga $\mathrm{F}$ sebesar 11.443 dengan nilai signifikan 0,001 yang lebih kecil dari alpha 0,05 atau taraf kepercayaan 95\%. Hal ini mengindikasikan bahwa persamaan regresi yang terbentuk antara variabel budaya organisasi dengan kinerja guru dapat diterima dengan keberadaannya. Hasil uji T diketahui bahwa nilai signifikasi sebesar 0,001, dengan konstanta 37.060, sedangkan persamaan regresi sebesar 3.383. dan nilai signifikasi sebesar 0,001 lebih kecil dari nilai signifikasi alpha 0,05. Jadi dapat ditarik kesimpulan bahwa kinerja guru di SMA Negeri 1 Pariangan dipengaruhi oleh budaya organisasi. Jadi budaya organisasi berpengaruh signifikansi sebesar 11,9\% terhadap variabel kinerja guru dan sisanya 88,1\% ditentukan oleh faktor lain yang belum teramati.

\section{Uji Hipotesis Ketiga}

Pengujian terhadap hipotesis dilakukan dengan analisis korelasi dan model regresi berganda (multivariat) antara variabel iklim organisasi $\left(\mathrm{X}_{1}\right)$ dan variabel budaya organisasi $\left(\mathrm{X}_{2}\right)$ dengan Variabel terikat kinerja guru $(\mathrm{Y})$. Persamaan regresi yang 
dikemukakan adalah $\hat{Y}=a+\beta 1 X 1+\beta 2 X 2$. Besarnya koefisien korelasi ganda antara variabel $\mathrm{X}_{1}$ dan $\mathrm{X}_{2}$ dengan $\mathrm{Y}$ (ry1-2) sebesar 0,540 dan $\left(\mathrm{r}^{2} \mathrm{y} 1-2\right)$ sebesar 0,292 dengan taraf signifikan $(\operatorname{sig}=0,000)<0,05$. Hal ini menunjukkan bahwa iklim organisasi $\left(\mathrm{X}_{1}\right)$ dan budaya organisasi $\left(\mathrm{X}_{2}\right)$ mempunyai pengaruh yang signifikan terhadap kinerja guru $(Y)$. Persamaan regresi ganda variabel iklim organisasi dan budaya organisasi terhadap kinerja guru adalah $\hat{Y}=27,031+$ 0,297X1 + 0,168X2, dari rangkuman hasil analisis regresi ganda diatas menunjukkan bahwa $F$ sebesar 9,262 dengan taraf signifikan 0,000. Dapat disimpulkan bahwa persamaan regresi ganda sangat berarti dan dapat digunakan untuk memprediksi variasi yang terjadi pada kinerja guru melalui variabel iklim organisasi dan budaya organisasi.

Berdasarkan hasil pengujian diatas hipotesis ketiga yang menyatakan iklim organisasi dan budaya organisasi secara bersama-sama berpengaruh signifikan terhadap kinerja guru, telah teruji secara empiris dan dapat diterima pada taraf 95\%. Hal ini berarti bahwa variabel iklim organisasi dan budaya organisasi bersamasama mempengaruhi variabel kinerja guru sebesar $29,2 \%$, sisanya $70,8 \%$ diperkirakan berasal dari variabel lain yang belum diamati.

Hasil pengujian ini juga menemukan besar sumbangan masing-masing variabel bebas terhadap variabel terikat. Sumbangan efektif iklim organisasi dengan kinerja guru sebesar $14,7 \%$ dan sumbangan relatifnya sebesar 50,3\%. Budaya organisasi dengan sumbangan efektif sebesar $14,5 \%$ dan sumbangan relatifnya sebesar 49,7\%. Dalam sumbangan efektif ditemukan bahwa sumbangan total iklim organisasi dan budaya organisasi dalam penelitian ini sebesar $29,2 \%$ berarti ada $70,8 \%$ variasi kinerja guru berhubungan dengan variabel yang tidak diikutkan dalam penelitian ini.

\section{PEMBAHASAN}

\section{Iklim Organisasi}

Berdasarkan deskripsi data yang telah disajikan dari hasil penelitian diatas tentang variabel $\left(\mathrm{X}_{1}\right)$ iklim organisasi secara umum berada dalam kategori baik dengan persentase $84,73 \%$. Secara per indikator diketahui bahwa variabel iklim organisasi dengan indikator tanggung jawab kerja berada pada tingkat pencapaian $86,1 \%$ atau kategori baik. Indikator hubungan antar personil disekolah dengan tingkat pencapaian $83,72 \%$ atau kategori baik, dan indikator dukungan kerja dengan pencapaian $84,56 \%$ jugaberada pada kategori baik.

Hasil penelitian diatas didukung oleh penelitian Herman Djailani dan Ibrahim (2014: 157) tentang pengaruh iklim organisasi dan kepuasaan kerja terhadap kinerja guru. Hasil pengujian hipotesis pertama menyatakan: $y x 1 \quad r \geq \mathrm{r}$ tabel $(1 / 2.0,05,49)$ atau $(0,7401>0,2759)$, maka hasil penelitian ini menolak Ho dan menerima $\mathrm{Ha}$, maka disimpulkan bahwa iklim organisasi secara langsung berpengaruh signifikan terhadap tinggi rendahnya kinerja guru. Besarnya pengaruh iklim organisasi secara langsung terhadap kinerja guru adalah $(0,7401>0,2759)=55 \%$.

\section{Budaya Organisasi}

Hasil penelitian membuktikan bahwa budaya organisasi berada dalam kategori baik, dengan persentase $88,91 \%$. Selanjutnya capaian skor indikator inisiatif 
individual dengan tingkat pencapaian 90,53\% berada pada kategori sangat baik. Indikator toleransi dengan tingkat pencapaian $87,2 \%$ atau baik. Indikator pengarahan dengan pencapaian $86,8 \%$ atau baik. Indikator integrasi dengan pencapaian $84,4 \%$ atau baik. Indikator dukungan manajemen dengan pencapaian $87,2 \%$ atau baik. Indikator kontrol dengan pencapaian 91,33\% berada pada kategori sangat baik. Indikator identitas dengan pencapaian $89,5 \%$ atau baik. Indikator sistem imbalan dengan pencapaian 90,13 atau sangat baik. Indikator toleransi terhadap konflik dengan pencapaian 91,2\% kategori sangat baik. Indikator pola komunikasi dengan pencapaian 90,8\% atau kategori sangat baik.

Hasil penelitian diatas memperlihatkan bahwa keterkaitan dengan penelitian yang telah dilakukan oleh Hermawan (2016: 13) tentang hubungan budaya organisasi dengan kinerja guru SMK - SPP Bandung Jawa Barat. Hasil penelitian ini membuktikan bahwa terdapat hubungan budaya organisasi dengan kinerja guru dan kontribusi budaya organisasi terhadap kinerja guru sebesar $62,41 \%$.

\section{Kinerja Guru}

Kinerja guru secara umum berada dalam kategori baik, dengan capaian $86,49 \%$. Indikator perencanaan pembelajaran dengan tingkat pencapaian 86,64\% atau kategori baik. Indikator pelaksanaan pembelajaran dengan tingkat pencapaian $87,2 \%$ dengan kategori baik dan Indikator evaluasi pembelajaran dengan tingkat pencapaian 85\% juga kategori baik.

Temuan ini didukung oleh hasil penelitian Sunuharyo (2017: 14-20) tentang Pengaruh Iklim Organisasi dan Budaya Organisasi Terhadap Kinerja Karyawan
(Studi pada Karyawan PT.PG Krebet Baru Malang) Hasil penelitiannya variabel bebas iklim organisasi dan budaya organisasi mempunyai pengaruh signifikan secara simultan terhadap kinerja karyawan di PT.PG Krebet Baru Malang, hal ini dapat dibuktikan bahwa nilai $\mathrm{F}$ hitung $=51,272>$ $\mathrm{F}$ tabel $=3,13$ atau nilai sig $\mathrm{f}(0,000)<\alpha$ $(0,05)$.

\section{Pengaruh Iklim Organisasi dan Budaya Organisasi Secara Bersama-sama terhadap Kinerja Guru}

Iklim organisasi dan budaya organisasi secara bersama-sama berpengaruh terhadap kinerja guru di SMA Negeri 1 Pariangan. Hal itu dibuktikan dengan uji hipotesis diterima dan telah diuji dengan taraf kepercayaan 95\%. Selanjutnya diinterpretasikan bahwa iklim organisasi dan budaya organisasi berpengaruh signifikansi terhadap kinerja guru di SMA Negeri 1 Pariangan sebesar $29,2 \%$.

Hasil penelitian diatas didukung oleh penelitian Afrizal dan Kasmirudin (2013: 183) yang menunjukkan bahwa hasil perhitungan secara statistik didapatkan koofisien korelasi multiple (R) bernilai 0,329 artinya terdapat hubungan positif antara variabel bebas (iklim organisasi dan budaya organisasi) secara simultan terhadap variabel terikat (kinerja) pegawai rektorat Universitas Riau. Hasil nilai koofisien determinasi (R2) sebesar 0,108 yang artinya bahwa sebesar $10,8 \%$ dari iklim organisasi dan budaya organisasi mempengaruhi kinerja pegawai rektorat Universitas Riau. 


\section{PENUTUP}

\section{Kesimpulan}

Berdasarkan hasil penelitian dan analisa tentang kinerja guru di SMA Negeri 1 Pariangan, berkaitan dengan iklim organisasi dan budaya organisasi, dapat disimpulkan bahwa: (1) Terdapat pengaruh yang signifikansi antara iklim organisasi terhadap kinerja guru di SMA Negeri 1 Pariangan yang berada pada kategori sedang dengan persentase sebesar 20,1\%; (2) Terdapat pengaruh yang signifikansi antara budaya organisasi terhadap kinerja guru di SMA Negeri 1 Pariangan yang berada pada kategori sedang dengan persentase sebesar $11,9 \%$; (3) Terdapat pengaruh yang signifikansi antara iklim organisasi dan budaya organisasi secara bersama-sama terhadap kinerja guru di SMA Negeri 1 Pariangan yang berada pada kategori sedang sebesar 29,2\%. Hal ini membuktikan bahwa untuk meningkatkan kinerja di SMA Negeri 1 Pariangan dapat dilakukan melalui iklim yang kondusif dan budaya organisasi yang kuat.

\section{Saran}

Disarankan kepada kepala sekolah untuk menjadikan hasil penelitian ini sebagai referensi dalam menentukan kebijakan yang berkaitan dengan iklim organisasi dan budaya organisasi dalam rangka meningkatkan kinerja guru di SMA Negeri 1 Pariangan. Iklim organisasi dan budaya organisasi merupakan variabel yang dominan memberikan pengaruh dalam meningkatkan kinerja guru maka iklim dan budaya organisasi harus mendapatkan perhatian khusus dari kepala SMA Negeri 1 Pariangan.

\section{KEPUSTAKAANACUAN}

Afrizal dan Kasmiruddin. 2013. Iklim Organisasi, Budaya Organisasi, Dan Kinerja Pegawai. Jurnal Administrasi Pembangunan 2 (1), 183-188.

Firmansah, M., I., dan Santy. R., D. 2011. Pengaruh Iklim Organisasi dan Karakteristik Pekerjaan Terhadap Kepuasan Kerja Pegawai di Lingkungan Pemerintahan Daerah Kabupaten Sukabumi. Majalah Ilmiah Unikom, 6 (2), 225-253.

Hanafi, M. 2006. Manajemen Resiko, Yogyakarta: Unit Penerbit dan Percetakan Sekolah Tinggi Ilmu Manajamen YKPN.

Hardjana, A. 2006. Iklim Organisasi Lingkungan Kerja Manusiawi. Jurnal ilmu komunikasi. 3 (11), 1-36.

Herman, AR., D., dan Ibrahim., S. 2014. Pengarub Iklim Organisasi dan Kepuasaan Kerja Terbadap Kinerja Guru. Jurnal Administrasi Pendidikan Pascasarjana Universitas Syiah Kuala, 2 (4), 157-167.

Hermawan. 2016. Hubungan Budaya Organisasi Dengan Kinerja Guru Smk Spp Bandung Jawa Barat. TANZHIM Jurnal Penelitian Manajeme Pendidikan, 1 (1), 13-26.

Hutasoit, T. 2016. Pengaruh Iklim Oranisasi, Kepuasan Kerja Dan Motivasi Berprestasi Terbadap Kinerja Guru Studi Empiris di SMP Negeri Kecamatan Sipoholon Kabupaten Tapanuli Utara, 1(2), 1-16.

Kurniadin, D. dan Machali. 2012. Manajemen Pendidikan, Jogjakarta: Ar-Ruzz Media. 
Mulyadi. 2010. Kepemimpinan Kepala Sekolah dalam Mengembangkan Budaya Mutu, Malang: UIN-Maliki Press.

Mulyasa, E. 2005. Menjadi Guru Profesional Menciptakan Pembelajaran Kreatif dan Menyenangkan. Bandung: Remaja Rosdakarya.

Pratiwi, S., D. 2013. Pengaruh Motivasi Kerja, Kepuasan Kerja, Kepemimpinan Kepala Sekolah Menurut Persepsi guru, dan Iklim Sekolah Terbadap Kinerja Guru Ekonomi SMP Negeri di Kabupaten Wonogiri. Jurnal Pendidikan Insan Mandiri, 1 (1)

Rahimic, Z. 2013. Influence of Organizational Climate on Job Satisfaction in Bosnia and Herregovina Companies. International Business Research, 6 (3), 129-139.

Rusu, G., dan Avasilcai, S. 2013. Linking Human Resources Motivaion to Organizaional Climate. Internaional Symposium in Management 2013. Procedia
Social and Behavioral Sciences, 124 (1), 51-58.

Saifulloh, M., M., dan Hermanto. 2012. Strategi Peningkatan Mutu Pendidikan di Sekolah. Jurnal Sosial Humaniora, 5 (2), 206-216.

Sarjana, S. 2012. Pengarub Supervisi dan Iklim Organisasi Terbadap Kepuasan Kerja. Jurnal Pendidikan, 42 (2), 173-186.

Soetopo, H. 2010. Perilaku Organisasi, Bandung: PT Remaja Rosdakarya.

Sunuharyo A., R., B., S. 2017. Pengarub Iklim Organisasi Dan Budaya Organisasi Terhadap Kinerja Karyawan (Studi Pada Karyawan Pt.Pg Krebet Baru Malang). Jurnal Administrasi Bisnis, 1 (53), 14-20.

Umar, U. 2007. Menjadi Guru Profesional. Bandung: PT. Remaja Karya.

Wibowo. 2001. Manajemen Perubahan, Jakarta: Rajawali Pers. 